\title{
The Effect of Prolactin on the Lecithin Content of Fetal Rabbit Lung
}

\author{
Margit Hamosh and Paul Hamosh \\ From the Department of Physiology and Biophysics, Georgetown University School of Medicine \\ and Dentistry, Washington, D.C. 20007
}

\begin{abstract}
A B S TRACT $1 \mathrm{mg}$ ovine prolactin was injected intramuscularly into rabbit fetuses (24th day of gestation) located in one of the two uterine horns exposed by laparotomy $(n=12)$. Fetuses in the other uterine horn were injected with an identical volume of vector and served as controls $(n=13) .2$ days later the fetuses were removed by a second laparotomy and sacrificed. Analysis of lung tissue composition yielded the following results: $(a)$ the prolactin-treated group of fetuses showed $40 \%$ higher total lung phospholipid content $(17.0 \pm 0.8 \mu \mathrm{mol} / \mathrm{g})$ than the control group $(12.2 \pm 0.5 \mu \mathrm{mol} / \mathrm{g}) ;(b)$ the prolactin-treated group had a $67 \%$ higher lung lecithin content $(8.7 \pm 0.8 \mu \mathrm{mol} / \mathrm{g})$ than the control group $(5.2 \pm 0.4 \mu \mathrm{mol} / \mathrm{g}) ;(c)$ dipalmitoyllecithin accounted for $67 \%$ of total lung lecithin in the prolactin-treated group and $44 \%$ in the control group. These differences were statistically highly significant $(P<0.001)$. However, between the prolactintreated and the control groups, there were no statistically significant differences in body weight and length, lung weight, the ratio of lung weight to body weight, DNA, protein and, water content. These results suggest that prolactin might be a trigger of lung surfactant synthesis in the rabbit fetus.
\end{abstract}

\section{INTRODUCTION}

Lung surfactant is a complex phospholipid lining the lung alveoli and is essential for normal pulmonary function (1). Surfactant deficiency is the primary

Received for publication 9 December 1976 and in revised form 7 February 1977. factor responsible for the respiratory distress syndrome of the newborn (2). This disease affects predominantly premature infants and is associated with immaturity of the biochemical pathways leading to adequate surfactant synthesis. Toward the end of gestation the fetal lung begins to produce surfactant (3), which is probably synthesized, stored, and secreted by the type II alveolar pneumocyte (4). Synthesis of surfactant can be accelerated by the administration of corticosteroids $(5,6)$ in pharmacologic doses. However, Mescher et al. (7) have shown that the appearance of pulmonary surfactant precedes the rise in plasma corticoids in fetal lambs. This observation would suggest that corticosteroids are not the natural trigger of surfactant synthesis. Evidence is accumulating to show that surfactant synthesis is affected by a number of hormones: association between low thyroid activity at birth and respiratory distress syndrome has been described (8); low maternal plasma estrogen levels have been linked to respiratory distress in the newborn (9). Estrogens might have a direct effect on the fetal lung (10) or could affect lung maturation indirectly by stimulating fetal prolactin secretion $(11,12)$.

Human fetal serum prolactin (13) rises sharply before an increase in the level of pulmonary surfactant (14). The purpose of this study is to investigate the effect of prolactin administration on the phospholipid level of fetal rabbit lung.

\section{METHODS}

Pregnant white New Zealand rabbits (B and $H$ Rabbitry, Rockville, Md.) were used in these experiments; gestational 
age was known within $2 \mathrm{~h}$, by observation of mating. Three 24-day pregnant does were anesthetized with sodium pentobarbital, and the uterus was exposed by a midline abdominal incision under semisterile conditions. Two to four fetuses in the same horn were injected through the intact transparent uterine wall intramuscularly into the shoulder or rump, with $1 \mathrm{mg}(0.05 \mathrm{ml})$ of prolactin. The prolactin used was a highly purified preparation which contained only trace amounts of the following hormones: growth hormone 0.010 $\mathrm{IU} / \mathrm{mg}$, thyroid-stimulating hormone $0.0040 \mathrm{USP} \mathrm{U} / \mathrm{mg}$, luteinizing hormone $0.0040 \mathrm{NIH}-\mathrm{LH}-\mathrm{S} 1 \mathrm{U} / \mathrm{mg}$, and follicle-stimulating hormone $0.020 \mathrm{NIH}-\mathrm{FSH}-\mathrm{S} 1 \mathrm{U} / \mathrm{mg}$. An equal number of fetuses in the contralateral uterine horn received $0.05 \mathrm{ml}$ buffer. 2 days later a second laparotomy was performed. The uteri were clamped in situ, resected, and transferred to a saline bath at $37^{\circ} \mathrm{C}$. The fetal sacs were delivered individually, and umbilical tape was tied immediately around the fetal neck and sac to prevent breathing. Crown-rump lengths and body weight were measured in all fetuses; the lungs were rapidly removed, and specimens were immediately taken for analysis. Methods of analysis and references are given in the legends to Tables I and II.

\section{RESULTS}

Prolactin administration to 24-day-old fetal rabbits caused a 36\% increase in the level of total lung phospholipid; lecithin concentration, however, rose $67 \%$ after prolactin treatment: $8.77 \pm 0.81 \mu \mathrm{mol} / \mathrm{g}$ in pro-

TABLE I

Effect of Prolactin on Phospholipid Content of Fetal Rabbit Lung

\begin{tabular}{lcccc}
\hline Treatment* & $\begin{array}{c}\text { Number of } \\
\text { experiments }\end{array}$ & Phospholipid $\ddagger$ & Lecithin & $\begin{array}{c}\text { Dipalmitoyl- } \\
\text { lecithin }\end{array}$ \\
\hline & & & $\mu$ mollg wet wt & \\
Prolactin & 12 & $17.0 \pm 0.85^{\prime \prime}$ & $8.77 \pm 0.81^{\prime \prime}$ & $6.00 \pm 0.35^{\prime \prime}$ \\
Control & 13 & $12.16 \pm 0.5$ & $5.23 \pm 0.44$ & $2.30 \pm 0.10$ \\
\hline
\end{tabular}

Results are Mean \pm SEM.

The fetuses, prolactin-treated and controls, were the offspring of three does.

* Purified prolactin (ovine NIH-P 511, potency $26.4 \mathrm{IU} / \mathrm{mg}$ ) was dissolved on the day of the experiment in sterile buffered saline $\left(0.85 \% \mathrm{NaCl}-0.1 \mathrm{M} \mathrm{NaHCO}_{3} \mathrm{pH} 8.8-9.0\right)$ to give a concentration of $20 \mathrm{mg} / \mathrm{ml}$. The hormone was injected i.m. $1.0 \mathrm{mg} / 0.05 \mathrm{ml}$ to each fetus at 24 days in utero; controls received $0.05 \mathrm{ml}$ buffered saline $\mathrm{pH} 8.8-9.0$ i.m. The lungs were analyzed 2 days later.

$\ddagger$ Lipids were extracted and washed according to Folch and Sloane Stanley (27). Phospholipids were separated by thinlayer chromatography on silica $\mathrm{G}$ gel plates (4) and quantitated by phosphorus determination (28).

§Dipalmitoyllecithin was isolated by column chromatography (29) after treatment of total lung lipids with osmium tetroxide (29). The purity of the dipalmitoyllecithin fraction was checked by thin-layer chromatography (29) and by analysis of the diglyceride formed after incubation of lung dipalmitoyllecithin with phospholipase C (30).

"Values significantly different from control $(P<0.001)$.
TABLE II

Effect of Prolactin on Fetal Growth and Lung Composition

\begin{tabular}{lcc}
\hline & Prolactin & Control \\
\hline Number of fetuses & 12 & 13 \\
Body weight, $g$ & $19.06 \pm 0.86$ & $18.44 \pm 1.06$ \\
Length, cm $^{*}$ & $6.72 \pm 0.13$ & $6.82 \pm 0.16$ \\
Lung wt, $m g$ & $480 \pm 0.13$ & $510 \pm 40$ \\
Lung wet wt, \% of body $w t$ & $2.48 \pm 0.13$ & $2.65 \pm 0.025$ \\
Lung dry wt, \% of wet $w t$ & $12.75 \pm 0.51$ & $12.13 \pm 0.50$ \\
DNA, $m g / g$ lung $\ddagger$ & $6.87 \pm 0.32$ & $7.00 \pm 0.38$ \\
Protein, $m g / g$ lung $\S$ & $58.20 \pm 3.6$ & $58.80 \pm 2.1$ \\
\hline
\end{tabular}

Results are mean \pm SEM.

Details on hormone administration are given in the footnote to Table I.

* Crown-rump length.

$\$$ DNA was determined according to Burton (31) by using calf thymus as reference standard.

\$ Protein was determined by the method of Lowry (32) with crystalline bovine albumin as standard.

lactin-treated vs. $5.23 \pm 0.44 \mu \mathrm{mol} / \mathrm{g}$ in control littermates (Table I). Dipalmitoyllecithin, the chief surface active component of lung surfactant, made up $67 \%$ of the lung lecithin fraction in prolactin-treated fetuses, whereas it amounted to only $44 \%$ of lung lecithin in controls (Table I). The rise in lung lecithin levels after prolactin administration was not the result of surgical stress, since the controls, fetuses in the contralateral uterine horn, were subjected to the identical surgical procedure and injection of vector. Measurements of body weight and length showed that prolactin-treated fetuses and their control littermates did not vary by more than $2-4 \%$ (Table II). In prolactin-treated vs. control fetuses, lung weight, lung-weight to bodyweight ratio, DNA, protein, and water content were $<8 \%$ lower (Table II).

\section{DISCUSSION}

The above findings show that administration of prolactin in pharmacological amounts (1 mg/fetus) leads to an increase in lecithin levels and especially to a rise in dipalmitoyllecithin, the surface active component of lung surfactant. Although we have at present no information on the physiological level of prolactin in the rabbit fetus, and cannot evaluate the effect of administration of such a dose, we suggest that fetal serum prolactin could play a role in lung maturation. Although we have no data on fetal serum prolactin levels, a decrease in maternal and neonatal urinary estrogen levels has been linked to the subsequent development of the respiratory distress syndrome in the neonate (9). Indirect evidence supports a role for prolactin in lung development; fetal prolactin secretion is stimulated by the high plasma estrogen levels 
characteristic of gestation (15). Stress causes a marked rise in serum prolactin levels (16), as well as in glucocorticoid levels (17).

The presence of glucocorticoid receptors in fetal lungs has been cited as evidence of a physiological role for steroids in surfactant maturation (18). However, in the human lung these receptors are present from early fetal life, throughout gestation, and even after birth (19). Thus, it seems that the presence of an active receptor system is not the limiting factor in the onset of glucocorticoid responsiveness in the fetal lung. We do not know the precise time of onset of glucocorticoid production in the human fetus and in a number of experimental animals; however, studies in fetal lambs clearly show that surfactant appearance in tracheal fluid precedes an increase in fetal glucocorticoid levels (7).

On the other hand, human fetal serum prolactin levels rise markedly before the appearance of pulmonary surfactant (13). A similar temporal relationship exists in fetal lambs (20).

It is well known that the target organ for prolactin is the mammary gland during pregnancy and lactation; recent studies indicate, however, that a number of other organs are affected by this hormone. There is evidence that prolactin plays a role in osmoregulation in mammals and that the kidney may be an important target organ for prolactin (15). Zinder et al. (21) have shown that adipose tissue becomes a target organ for prolactin during late pregnancy and lactation. Very high levels of prolactin are present in amniotic fluid (22); the onset of prolactin synthesis and storage in the fetal pituitary gland occurs early in gestation (23), and a steady rise in fetal serum prolactin after a 24-wk gestation has been reported (13). The role of prolactin in the fetus and newborn is unknown at present. A possible somatotropic function has been suggested (22), that would be similar to prolactin stimulation of protein and fat synthesis in the mammary gland. In addition to the mammary gland, prolactin binds specifically to a number of other tissues such as liver, adrenal, and kidney (24). Prolactin binding to fetal liver, kidney, and heart has been reported (25); however, binding of the hormone to fetal lung has not been studied. In addition to the stimulation of phospholipid synthesis, prolactin may also effect electrolyte secretion by the alveolar cells. A direct relationship between potassium and surfactant secretion into tracheal fluid has been shown in fetal lambs (7).

Lung maturation and surfactant synthesis could be under multiple hormone control. Thus, in addition to corticosteroids, thyroid hormones have been shown to stimulate lung maturation (26). Prolactin should be added to this growing list. The results of this study and the indirect evidence compiled suggest the pos- sibility that prolactin is a physiological trigger for surfactant maturation.

\section{ACKNOWLEDGMENTS}

The authors thank H. Canter, Jr., R. Hankins, and B. L. Rollison for technical assistance. This study was supported by NHLBI grant HL 19056 and by a grant from the Council for Tobacco Research, U.S.A.

\section{REFERENCES}

1. Clements, J. A., R. F. Hustead, R. P. Johnson, and I. Gribetz. 1961. Pulmonary surface tension and alveolar stability. J. Appl. Physiol. 16: 444-450.

2. Avery, M. E., and J. Mead. 1959. Surface properties in relation to atelectasis and hyaline membrane disease. Am. J. Dis. Child. 97: 517-523.

3. Buckingham, S., and M. E. Avery. 1962. The time of appearance of lung surfactant in the foetal mouse. $\mathrm{Na}$ ture (Lond). 193: 688-689.

4. Darrah, H. K., and J. Hedley-Whyte. 1973. Rapid incorporation of palmitate into lung: site and metabolic fate. J. Appl. Physiol. 34: 205-213.

5. de Lemos, R. A., D. W. Shermeta, J. H. Knelson, R. Kotas, and M. E. Avery. 1970. Acceleration of appearance of pulmonary surfactant in the fetal lamb by administration of corticosteroids. Am. Rev. Respir. Dis. 102: 459-461.

6. Motoyama, E. K., M. M. Orzalesi, Y. Kikkawa, M. Kaibara, B. Wu, C. J. Zigas, and C. D. Cook. 1971. Effect of cortisol on the maturation of fetal rabbit lungs. Pediatrics. 48: 547-555.

7. Mescher, E. J., A. C. G. Platzker, P. L. Ballard, J. A. Kitterman, J. A. Clements, and W. H. Tooley. 1975. Ontogeny of tracheal fluid, pulmonary surfactant, and plasma corticoids in the fetal lamb. J. Appl. Physiol. 39: 1017-1021.

8. Cuestas, R. A., A. Lindall, and R. R. Engel. 1976. Low thyroid hormones and respiratory-distress syndrome of the newborn. Studies on cord blood. N. Engl. J. Med. 295: 297-302.

9. Charles, D., and S. C. Chattoraj. 1973. Possible role of estradiol $17 \beta$ and cortisol in the prevention of RDS. In Respiratory Distress Syndrome. C. A. Villee, D. B. Villee, and J. Zuckerman, editors. Academic Press, Inc., New York. 381-398.

10. Haynes, R. C., Jr., G. Mikhail, G. Eriksson, N. Wiqvist, and E. Diczfalusy. 1964. Oestradiol metabolism in the previable human foetus and in the foeto-placental unit. Acta Endocrinol. 45: 297-320.

11. Tyson, J. E., and H. G. Friesen. 1973. Factors influencing the secretion of human prolactin and growth hormone in menstrual and gestational women. Am. J. Obstet. Gynecol. 116: 377-387.

12. Shutt, D. A., I. D. Smith, and R. P. Shearman. 1974. Oestrone, oestradiol-17 $\beta$ and estriol levels in human foetal plasma during gestation and at term. J. Endocrinol. 60: 333-341.

13. Aubert, M. L., M. M. Grumbach, and S. L. Kaplan. 1975. The ontogenesis of human fetal hormones. III Prolactin. J. Clin. Invest. 56: 155-164.

14. Gluck, L., and M. V. Kulovich. 1973. Lecithin/sphingomyelin ratios in amniotic fluid in normal and abnormal pregnancy. Am. J. Obstet. Gynecol. 115: 539-546.

15. Frantz, A. G., D. L. Kleinberg, and G. L. Noel. 1972. Studies on prolactin in man. Recent Prog. Horm. Res. 28: 527-590. 
16. Hwang, P., H. Friesen, J. Hardy, and D. Wilansky. 1971. Biosynthesis of human growth hormone and prolactin by normal pituitary glands and pituitary adenomas. J. Clin. Endocrinol. Metab. 33: 1-7.

17. Sayers, G. 1950. Adrenal cortex and homeostasis. Physiol. Rev. 30: 241-320.

18. Ballard, P. L., and R. A. Ballard. 1972. Glucocorticoid receptors and the role of glucocorticoids in fetal lung development. Proc. Natl. Acad. Sci. U.S.A. 69: 2668-2672.

19. Ballard, P. L., and R. A. Ballard. 1974. Cytoplasmic receptor for glucocorticoids in lung of the human fetus and neonate. J. Clin. Invest. 53: 477-486.

20. Stokes, H., and J. M. Boda. 1968. Immunofluorescent localization of growth hormone and prolactin in the adenohypophysis of fetal sheep. Endocrinology. 83: 1362-1366.

21. Zinder, O., M. Hamosh, T. R. C. Fleck, and R. O. Scow. 1974. Effect of prolactin on lipoprotein lipase in mammary gland and adipose tissue of rats. Am. J. Physiol. 226: 744-748.

22. Fournier, P. J. R., P. D. Desjardins, and H. G. Friesen. 1974. Current understanding of human prolactin physiology and its diagnostic and therapeutic applications: a review. Am. J. Obstet. Gynecol. 118: 337-343.

23. Levina, S. E. 1968. Endocrine features in development of human hypothalamus, hypophysis, and placenta. Gen. Comp. Endocrinol. 11: 151-159.

24. Posner, B. I., P. A. Kelly, R. P. C. Shiu, and H. G.
Friesen. 1974. Studies of insulin, growth hormone and prolactin binding: tissue distribution, species variation and characterization. Endocrinology. 95: 521-531.

25. Kelly, P. A., B. I. Posner, T. Tsushima, and H. G. Friesen. 1974. Studies of insulin, growth hormone and prolactin binding: ontogensis, effects of sex and pregnancy. Endocrinology. 95: 532-539.

26. Wu, B., Y. Kikkawa, M. M. Orzalesi, E. K. Motoyama, M. Kaibara, C. J. Zigas, and C. D. Cook. 1973. The effect of thyroxine on the maturation of fetal rabbit lungs. Biol. Neonate. 22: 161-168.

27. Folch, J., M. Lees, and G. H. Sloane Stanley. 1957. A simple method for the isolation and purification of total lipids from animal tissues. J. Biol. Chem. 226: $497-$ 509.

28. Bartlett, G. R. 1959. Phosphorus assay in column chromatography. J. Biol. Chem. 234: 466-468.

29. Mason, R. J., J. Nellenbogen, and J. A. Clements. 1976. Isolation of disaturated phosphatidylcholine with osmium tetroxide. J. Lipid Res. 17: 281-284.

30. Kates, M. 1972. Techniques of Lipidology. American Elsevier Publishing Co., Inc., New York. 569 pp.

31. Burton, K. 1956. A study of the conditions and mechanism of the diphenylamine reaction for the colorimetric estimation of deoxyribonucleic acid. Biochem. J. 62: 315-323.

32. Lowry, O. H., N. J. Rosenbrough, A. L. Farr, and R. J. Randall. 1951. Protein measurement with the Folin phenol reagent. J. Biol. Chem. 193: 265-275. 